\title{
CRITICAL STUDY OF OPTIMIZATION OF ISLAMIC CORPORATE GOVERNANCE IMPLEMENTATION TO ACHIEVE COMPANY PERFORMANCE
}

\author{
Reza Widhar Pahlevi \\ Department of Management, Faculty of Economics \\ Universitas Islam Indonesia, Yogyakarta \\ rezawp@uii.ac.id
}

\begin{abstract}
Guidelines for Good Corporate Governance an Islamic perspective have a broader context, do not separate roles and responsibilities in all stakeholders actions under the auspices of Islamic sharia law. There are differences in concepts and perspectives between western perspective (Anglo Saxon and European) Good Corporate Governanceand Islamic perspectives. The difference in the very basic point of view that Good Corporate Governance is the Islamic perspective comes from tawhid, shari'ah, and the concept of shura. Islamic Good Corporate Governance guidelines focus on the role of stakeholders related to the company.

The development of science that occurs in the perspective of Good Corporate Governance begins on the basis of agency theory which states that there is a separation between ownership and management that has the potential to cause agency problems, ways to overcome agency problems through the implementation of Good Corporate Governance. Implementation of guidelines for Good Corporate Governance is an obligation for the company. This is more aimed at the existence of responsibility to the public (public accountability) relating to the company's operational activities and it is expected that the company can comply with the provisions outlined in a positive law. In addition, this is related to the level of compliance of sharia with sharia principles as described in the Qur'an, Hadith, and Ijma 'of the Ulama. Research related to Good Corporate Governance in the Islamic perspective with the achievement of company performance is expected to provide an overview of the Good Corporate Governance framework that recognizes the rights of stakeholders as determined by law and encourages active cooperation between companies and stakeholders to create employee welfare, performance, and corporate sustainability.
\end{abstract}

Keywords: Islamic Corporate Governance, Agency Theory and Performance

\begin{abstract}
Abstrak
Pedoman Tata Kelola Perusahaan perspektif Islam memiliki konteks yang lebih luas, tidak memisahkan peran dan tanggung jawab dalam semua tindakan pemangku kepentingan di bawah naungan hukum syariah Islam. Terdapat perbedaan konsep dan perspektif antara perspektif barat (Anglo Saxon dan Eropa) Good Corporate Governance dan perspektif Islam. Perbedaan dalam sudut pandang yang sangat mendasar bahwa Tata Kelola Perusahaan perspektif Islam adalah berasal dari tauhid, syari'ah, dan konsep syura. Pedoman Tata Kelola Perusahaan perspektif Islam berfokus pada peran pemangku kepentingan yang terkait dengan perusahaan.
\end{abstract}

Article History

Received : 2019-03-26

Revised : 2010-04-20

Accepted : :2010-05-10

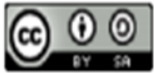

This is an open access article under the CC-BYSA License 
Perkembangan ilmu yang terjadi dalam perspektif Good Corporate Governance dimulai atas dasar teori keagenan yang menyatakan bahwa ada pemisahan antara kepemilikan dan manajemen yang berpotensi menyebabkan masalah keagenan, cara mengatasi masalah keagenan melalui penerapan Tata Kelola Perusahaan. Penerapan pedoman Tata Kelola Perusahaan adalah kewajiban bagi perusahaan. Hal ini lebih ditujukan pada adanya tanggung jawab kepada publik (akuntabilitas publik) yang berkaitan dengan kegiatan operasional perusahaan dan diharapkan perusahaan dapat mematuhi ketentuan yang diuraikan dalam undang-undang positif. Selain itu, terkait dengan tingkat kepatuhan syariah dengan prinsip-prinsip syariah seperti yang dijelaskan dalam Al Quran, Hadist, dan Ijma 'para Ulama. Penelitian terkait Good Corporate Governance dalam perspektif Islam dengan pencapaian kinerja perusahaan diharapkan dapat memberikan gambaran umum tentang kerangka kerja Good Corporate Governance yang mengakui hak-hak pemangku kepentingan sebagaimana ditentukan oleh hukum dan mendorong kerja sama aktif antara perusahaan dan pemangku kepentingan untuk menciptakan kesejahteraan karyawan, kinerja, dan keberlanjutan perusahaan.

\section{Kata Kunci: Tata Kelola Perusahaan Islam, Teori Agensi dan Kinerja}

\section{Introduction}

Good Corporate Governance is associated with the achievement of company performance. Based on agency theory, maximizing shareholder worth shows the purpose of getting better performance through profit maximization. Most previous studies generally measured corporate governance from the lens of maximizing shareholder value such as Profitability (Return on Assets, Return on Equity, and Tobins Q). Islamic Good Corporate Governance always associates the principles of behaviour and business ethics with things that are transcendental and faithful. This is a consequence of Muslims' faith in God.
So the value of Tauhid (monotheism) is the basis of any belief, thought and behavior of a Muslim, including in the understanding of Good Corporate Governance.

One of the principles Islamic Good Corporate Governance of Tauhid (monotheism) is the principle of accountability and justice. The value of islam always encourage each people to be fair in every aspect both in the matters of faits, sharia, or morals as the consequence of faith and to achieve the degree of piety. In line with the above verse, one of the principles in the implementation of corporate governance is accountability and fairness (equality or justice) which is intended to bring the management of 
the company fair to all stakeholders. If it is associate with sharia, justice should include spiritual and material aspects. Then the meaning of fair can be expanded at any principles, content in the corporate governance and other values that can be raised over the implementation of justice (Indrawaty \& Wardayati, 2016).

Ramli \& Ramli (2016) argued that taking from a different view given the islamic religion which accent twenties on the social equilibrium and justice, islamic bans any opportunistic business practice that aims solely for the lucrative motive at the expence of other stakeholders (society). In line with that, based on the traditional agency theory the monitoring function of the board of director could help to bridge the gap exist between the shareholders principle and management (agent) due to divergence of their interest by striving for the shareholder's profit maximization. There is needs a monitor between the board of commissioners and directors to exercise control in minimizing conflicts of interest based on universal GCG concepts that are closely related to the islamic value. The principles of Good Corporate Governance are in line with the the islamic value.

Since islam upholds the concept of social accountability and social disclosure, islam encourage the profit making motive as a way to recover the possible risk an uncertainty in business but gaining such as reward and moderation level. Perhaps the conflicting issue of achieving the desired threshold of profit moderation could be resolved through conducting and interview with respective sharia scholars, as a way forward to protect the benefits of the society by propageting such profit moderation practices in business.Islam encourages full disclosure reports, is honest and transparent in every business transaction to ensure that the company or institution is a form of obeying Islamic law. Islamic Good Corporate Governance focuses on the roles and responsibilities of the Sharia supervisory board whose function is to 
oversee the company's operations and ensure that all activities in the company are in line with Islamic principles (Hayat \& Hassan, 2016; Hasan, 2009).

Some previous studies found good corporate governance from an Islamic perspective (Ramli \& Ramli, 2016) given a different view, to examine to which extent the companies with Good Corporate Governance scores will have good performance from an islamic perspective (proxiet by profitabilty measurement). In Malaysia, among the earlier existence of corporate governance reform in the early 2000s, where the malaysian code corporate governance and the Kuala Lumpur stock exchange listing requirements which both have greatly emphasized on the enhancement of exercising Good Corporate Governance pratices and transpracy disclosure toward the public listed company. The corporate accountability would determine the way the company is being operated and manage and it is performance consequences since the shareholders rely heavily on the corporate governance. Hence, the idea of conventional agency theory is created due to bridging the gap between the management and the absence of owners (shareholders) to the operational activities with the presence of a crutial monitoring mechanism, the board of directors.

In addition, Mansor (2015) stated that there is no real definition of Good Corporate Governance, there are substantial differences in the definition of Good Corporate Governance and different perspectives from policy makers, practitioners and academics. More precisely, the core of corporate governance depends on who controls the company and the extent to which ownership separation from supervision is crucial. There is general consensus that the fundamental problem of corporate governance is related to the growth of the company through the separation of management and ownership roles. 
Tapanjeh (2009), analyzing the comparison of Good Corporate Governance guidelines seen from two perspectives, namely Good Corporate Governance in an Islamic perspective that has a wider range and the absence of separation of roles and responsibilities in actions and obligations under Islamic law. According to Hasan (2009) that there is a difference between Good Corporate Governance in the west (Anglo-Saxon) and corporate governance in an Islamic perspective. Good Corporate Governance in an Islamic perspective begins in the concept of Tawheed, Sharia, and Shura.

Nowadays Good Corporate Governance issues are developing, according toIqbal \& Mirakhor (2012), there are four factors that lead to the development of Good Corporate Governance, among others, First, the growth of institutional investors, second, increased concern and criticism of weak monitors and control of public companies, third, there is a change in viewpoint involving stakeholders as part of Good Corporate Governance, fourth, increasing globalization and liberalizing investor activity. From these four factors, there is a direct correlation between changes in people's views in Good Corporate Governance and the emergence of economic and social problems that are motivated by the development of the economy and optimal social relations both internally and externally between companies and stakeholders outside company. The application of the Good Corporate Governance is a must for an institution with the form of responsibility to the community relating to the operational activities of the organization. The operational activities of the organization cannot be separated from the demands of implementing organizational governance based on sharia principles or known as Islamic Corporate Governance.

Research related to Islamic corporate governance with the achievement of company performance 
is expected to provide an overview of the corporate governance framework recognizing the rights of stakeholders as determined legally and encourage active cooperation between companies and stakeholders in creating employee welfare, performance and sustainability business.

\section{Literatur Review}

Tricker (2009) argues that there are problems regarding culture that cannot be used as rational reasons for the weak implementation of corporate governance in a country. The inability to identify failure to implement good corporate governance on the grounds of cultural aspects is a brief perspective and tends to be simplified. The implications of cultural differences can be explained in the good corporate governance model including:

\section{a. The American Rule Based Model}

The initial model and thinking of corporate governance according to experts tended to lead to the
Anglo-Saxon model which was characterized by a "one tier" model that was different from the European model which was characterized by the "two tier" model. But in development, there are fundamental differences between the United States and United Kingdom models and other commonwealth models. According to Steiner \& Steiner (2009) argues that the main characteristic that underlies the American corporate governance model is the existence of another independent board of directors (BoD) that has similarities with the British corporate governance model in which American capital market authorities require each company to have an audit committee, nomination committee, and remuneration committee. Shaw (2003) states that in the American model, the 
existence of shareholders has a limited influence on identifying members of the Board of Directors.

Furthermore, Kakabadse et al (2005) stated that shareholders as company owners can express dissatisfaction only through mechanisms in voicing complaints or selling company shares. Brennan \& Solomon (2008) states that the choice of voting strategies that can be carried out by shareholders reflects dissatisfaction with company management. Meanwhile, the British model or commonwealth model, the existence of shareholders with $10 \%$ ownership rights in public companies can force extraordinary meetings and have the right to choose strategic matters or replace members of the Board of Directors. In the UK model, the position of Chairperson of the
Board of Directors (Indonesia: President Commissioner) and Chief Executive Officer (Indonesia: President Director) is held by different individuals. However, in the American model both positions (Board Chair and Chief Executive Officer) are usually held by the same individual in a company. Although there is strong pressure to separate positions by different individuals (rule sharing), in practice this has not been applied in general. In the corporate structure in Indonesia in accordance with the laws and regulations of the company, members of the board of directors may not be members of the board of commissioners in the same company at the same time in a company.

The fundamental difference between the American model and the British model is that the 
American model is based on Rule Based so that in assessing the implementation of corporate governance, regulators will question whether the company's actions are legal? While the British model is based on the principle-based questions proposed by regulators whether the company's actions are correct? Thus in the American model, corporate governance is strictly regulated through legal laws and mandatory rules to support the implementation of the corporate governance model so that members of the Board of Directors will receive sanctions if they do not comply, the role of regulators is to ensure that companies operating in the country it is in accordance with the rules (Lukviarman, 2016).

b. The United Kingdom/Common Wealth Principle Based Model
As found in models in America, English law or Commonwealth models are based on "Common Law" which is rooted in laws developed based on "The Case Law". The United Kingdom applies the corporate governance principle model which is regulated through the code of principles of good corporate governance or good practice in determining the form of responsibility for structural governance elements that are not based on law. In this concept the company must report that by following and adhering to the principles of corporate governance established in accordance with the standards of corporate governance guidelines. On this basis, the British pattern is often referred to as compliance or explaining the corporate governance approach.

Although between various 
countries the commonwealth of corporate governance for public companies listed on the capital market has several differences, the differences are relatively insignificant with the guideline of the Commonwealth's corporate governance and need to require: a) Non-Exclusive Independent Director, b) Audit Committee, c) Remuneration Committee; d) Nomination Committee, and e) High level of transparency and accountability. Another distinguishing feature of the British or Commonwealth model with the American model is that corporate governance guidelines for countries that embrace the Commonwealth or Commonwealth corporate governance model require the separation of the Chief Executive Officer and the Main Board (Lukviarman, 2016).

\section{c. The Continental European Two Tier Model}

The main characteristics of governance guidelines in the European Continent are characterized by the tendency of small and less liquid financial markets so that the role of the market to oversee companies as part of the governance mechanism is weak. In various countries such as Italy and France, it can be identified that corporate financing through bank loans is usually used to fund the company's needs. Banking institutions can play a role in corporate activities, especially in Germany. According to Kakabadse et al (2005) argued that the need for a "two tier" board system in the corporate structure in accordance with the pattern of social contracts commonly found in the social culture of European communities such as Germany, 
the Netherlands, Italy and France often accommodates various social aspects of the company. For example, the Codetermination Rules such as those found in Germany require that half of the Board of Commissioners be the representative of workers selected through the Association of Trade Unions. While half of the members of the Board of Commissioners are from representatives of the owners of capital determined and selected by the shareholders at the General Meeting of Shareholders which aims to balance the interests of the owners and management of the company. The existence of Continental European corporate governance models differs significantly compared to American and British models. There are several criticisms of the European model of corporate governance that the position of the board of directors is more dominated by top management.

Monks \& Minow (2004) argue that management has limited information, advice and opinions that are usually obtained by independent nonexecutive directors such as those found in a "one tier" system. Another criticism is the effectiveness of the role of the Board of Commissioners who is considered not to have the power to be able to carry out the role of management oversight and control. Further criticism is related to the presence of workers' representatives in the Supervisory Board because they are considered to have potential in conflicts of interest because they can be separated between the interests of employees and the company's corporate institutions as a whole. 


\section{d. The Japaneese Business Network Model}

Members of the Board of Directors in the "Japaneese Business Network (Keiretsu)" model are part of the management or Board of Directors of other companies in the Keiretsu business network. However, Non-Executive Independent Directors as commonly found in other corporate governance models are rarely found in Japan (Tricker, 2009). Japanese company law accommodates the presence of Independent Director positions for companies established under Japanese law. Although the basis of the Japanese corporate governance model is the Joint Council, the Board of Directors can form various committees separately outside the Board of Directors' institutions so that the existence of this committee is considered similar to the supervisory board found in the European Continent that adheres to the "two tier" board system.

The Chairman of the Board of Directors and Senior Directors of various companies in Japan on the Keiretsu network meet regularly and hold regular meetings. Meetings with management and the managing director and other management teams are also carried out and are very important and carried out informally. In the Japanese corporate governance model based in Keiretsu, strength within the company is in top management, especially the President and Chair. Jensen (2000) states that the role of investors in the Japanese model is relatively small in relation to various aspects of the company. The Japanese model has a stakeholder model orientation not on shareholders, 
but the power over companies is in the Keiretsu network while the market for corporate control mechanisms is relatively small in the Japanese corporate governance model because there is no takeover of company shares.

e. Corporate Governance in Indonesia

Experts agree that the corporate governance system adopted by Indonesia follows the pattern of the Continental European System which can be explained using "Path Dependence Theory" (Lukviarman, 2016). The company's management system in Indonesia is strongly influenced by factors that depend on the company's structure and laws inherited by the Dutch because the initial existence of the company in Indonesia was started by the Dutch in the colonial period. Lukviarman (2016) explained that the main problem of implementing corporate governance began in the Adam Smith era as a result of the separation between ownership and control of corporate entities. The consequences of the separation cause conflicts of interest that can affect efforts to achieve company goals, namely increasing the value of the company. Efforts to reduce agency problems can be done through a series of mechanisms that work in a system with the main goal of creating a mechanism that functions as a controlling force to reduce conflicts of interest with companies or other stakeholders.

Based on the concept of No-One-Size-Fits-All OECD (1999) the control mechanism in the corporate governance system applied by a country has different characteristics from other countries. For 
example, in Anglo-Saxon countries whose market-based financial systems can rely more on oversight mechanisms, the reason is because market laws (capital markets, products, and labor) will work to discipline companies that do not comply with governance rules corporate governance, besides that internal controls also function well. Conversely, in developing countries that generally have a network-based financial system (network oriented) cannot fully rely on market mechanisms and supporting devices that do not yet have enough power to discipline companies because conditions in developing countries. The same thing also happened to internal controls that were relatively ineffective because the existence of the company's Board of Commissioners was not yet fully independent and free from interference from majority shareholders. According to Lukviarman (2016) the most fundamental constraints on the implementation of corporate governance in Indonesia are related to morals and ethics, for example public companies in Indonesia are generally patterned ownership that is concentrated in family relationships and generally joins family-based network businesses. With the character of the family as the majority owner, this bargaining power becomes very strong. Regardless of the existence or absence of laws and regulations can limit the space for movement, without a strong moral and ethical basis, the possibility of prioritizing group interests at the expense of the interests of society. 


\section{f. Islamic Good Corporate Governance}

Effendi (2016) revealed that the concept of Good Corporate Governance has to do with the existence of Islamic values. The principles of Good Corporate Governance are in line with Islamic values. The moral dimension of the implementation of Good Corporate Governance lies in the principles of accountability, responsibility, transparency and fairness. Honesty, responsibility, trustworthiness, and dependency and sensitivity to the environment are the goals of good corporate governance where good corporate governance is a way for companies to prioritize spiritual values such as disclosure, responsibility, trust, justice, and social responsibility. When compared to the exemplary attitude of the Prophet Muhammad like
Siddiq, Amanah, Tabligh, Fathanah, or in other words honest, trustworthy, responsible, intelligent, and concerned about the environment or society. A significant difference lies in the motivation for material ownership and satisfaction is often the main motive for someone to implement good corporate governance. If the results to be achieved are only motivated by material satisfaction, it will lead to various scandals which eventually end in destruction (Agustian, 2009).

The values, content, and objectives of good corporate governance have been discussed in the Qur'an and Al-Hadith. But the discussion of Islamic sources is of course not collected together but in the Qur'an an explanation of good corporate governance is spread. Even so, 
the values of Islam in the Qur'an are not contradictory, but rather explain and support each other. Although the term corporate governance is still new but the concept is contained in the Qur'an as in Surat Al-Baqarah verses 282283 about the transaction process which explains how important it is to carry out the records correctly so that there is no unfair treatment and explanation of this verse needed to explain the concept of transparency and disclosure in business agreements (Tikawati, 2016).

Good corporate governance has experienced significant developments, the concept of Good Corporate Governance requires improvement of the entire system and corporate structure which will be one value accepted in the business community. In principle, the application of Good Corporate Governance is relevant and in line with Islamic values. Islam requires that every aspect of life be governed by systems and structures that fulfill the best practices outlined by Allah SWT. Therefore, this ideal concept must continue and become an integral part of the complete and complete Islamic concept (Tikawati, 2016). In Islamic values the principles contained in good corporate governance are important principles in the activities and life of a Muslim. The application of Islamic principles is (justice), tawadzun (balance), mas'uliyah (accountability), morality (moral), siddiq (honesty), trust (fulfillment of trust), fatanah (intelligence), tabligh (transparency), hurriyah (independence), ikhsan (professional), wasathan (reasonableness), ghirah 
(militant sharia), idarah (management), khilafah (leadership), aqeedah (faith), ijabiyah (thinking positiv), raqabah (supervision), qiraah and islah (organizations that continue to learn and always make improvements) (Chapra \& Ahmed, 2002).Several studies have been carried out by other relevant parties to be made the basis of this research including as shown in the table presented on the appendix.

\section{Research Methods}

The approach in this study uses a qualitative approach with a literature review method. Research with a literature review method is a form of research that uses literature (reference) as the object of research. Literature is reviewed by using books and journals or articles with topics of Islamic corporate governance and general corporate governance.

\section{Result and Discussion}

The development of theory in the 21 st century produced a number of notes and thoughts on the concepts and implementation of corporate governance. There are several disciplines that contribute to the concept of corporate governance and these disciplines are expected to support the position of corporate governance as a multidisciplinary scientific field. As a strategic concept and within the strategic scope of the organization, the implementation of good corporate governance will affect business growth, competitiveness and continuity of the organization in the future. According to Tricker (2009) suggests that there are two major groups of theories that underlie corporate governance, namely agency theory and management theory. Both theories have similarities based on the assumptions of a restricted reality model, but have substantial differences. Agency theory is based on the theory of economic approaches while management theory is based on 
a legal perspective. In addition to a variety of advantages, each of the two perspectives has several weaknesses so that it becomes a theory limitation because it views similar phenomena from different perspectives.

There are several activities such as the formation of "The Sarbanes-Oakley" in America, guidelines for corporate governance in various developing countries and the establishment of governance institutions in Indonesia by forming the National Committee on Governance (KNKG). Referring to the National Committee on Governance Policy (KNKG) has basic guidelines for companies to implement Good Corporate Governance guidelines. Every company must ensure that the principles of Good Corporate Governance are applied to every aspect of business and at all levels of the company. The guidelines for Good Corporate Governance consisting of transparency, accountability, responsibility, independence, justice and equality are needed to achieve the company's business sustainability by prioritizing stakeholder interests.

a) Transparency

To maintain the level of objectivity in conducting business, companies must provide complete and relevant information in a way that is easily accessible and understood by stakeholders. The company must take the initiative to disclose not only those required by law, but also important matters for decision making by shareholders, creditors and other stakeholders.

b) Accountability

Companies must be able to account for their performance in a transparent and fair manner, the company must be managed correctly, measurably, and in accordance with the interests of the company by taking into account the interests of 
shareholders and other stakeholders. Accountability guidelines are a necessary condition for achieving performance.

c) Responsibility

Companies must comply with the laws and regulations to carry out responsibility for society and the environment so that long-term business continuity can be maintained and recognized as a good company.

d) Independency

In order to implement the Good Corporate Governance guidelines, companies must be managed independently so that each company organ does not dominate each other and does not intervene with each other.

e) Fairness

To carry out its activities, the company must pay attention to the interests of shareholders and other stakeholders based on the principles of justice and equality.

Looking at the profile of Asian companies with the majority of ownership being family companies. In fact, the position of family companies represents half to two-thirds of public companies traded on the Exchange in Asian countries. Priorities in the family that must be fulfilled and harmonious relations with other stakeholders can cause anxiety and doubt to foreign investors. Realizing this, members of Asian public companies work to create greater transparency and create stronger formal regulations (Anand, 2008).

There are implications for understanding the phenomenon of corporate governance that can be done universally but there are corporate governance practices in various countries that must be seen in accordance with the specific context of a country's environment. This is due to a variety of 
significant environmental differences, especially those related to legal, cultural and other institutional aspects (Lukviarman, 2016). This approach is in line with the paradigm of "One-SizeDon't-Not-Fits-All" proposed by the OECD (1999) to accommodate various questionable differences as well as dynamic cues in the concept of corporate governance. Differences in various aspects of the organizational environment that affect the practice of corporate governance can be explained through the effectiveness of internal control mechanisms in the corporate governance system implemented by a country.

According to Anand (2008), companies that focus on Corporate Governance guidelines will find themselves more able to move with changing times. The guidelines include:

a) Independence

Companies can apply the guidelines of Good Corporate
Governance only when the boards are independent. This means that there is not only a separation between the CEO and Chair role, but also that the board of directors must contain a high percentage of active independent members. Companies with a strong Corporate Governance structure must have an independent board of directors. Without the independence of the board, there will be no effective executive government, and the directors will not be able to fulfill obligations to shareholders.

b) Accountability

All members of the company's organs must be willing to take responsibility for all failures caused by their actions. Regulators and policy makers must focus on rebuilding accountability within the company. This means ensuring that members not only understand their responsibilities, 
but also the extent to which they will be responsible if they ignore these responsibilities. To accommodate this guideline, it is recommended that companies make a code of ethics and clear job descriptions so that all company organs have clear ideas about their vision and mission.

c) Responsibility

Apart from being responsible behavior, company organs must be responsible for their duties and obligations. This means that it is the responsibility of the organ of the company to ensure that they have all the necessary information needed to make the right decisions or complete work tasks according to the target.

\section{d) Reputation}

To be able to implement good corporate governance, company members must remember that this is not only about managing business practices, but also about creating harmonious relationships between the company and the community. By focusing on building harmonious relationships and not only complying with regulations, companies will remain in the code of ethics and applicable law.

There are some concerns that arise regarding the principles of corporate governance, especially when viewed from an Islamic perspective. The ethical component of every economic activity in Islam is to provide justice, prioritize honesty and justice and to ensure all parties have rights and obligations fulfilled. Islamic economics has experienced rapid progress over the past two decades with the encouragement as an important concern in developing Islamic enterprise systems. As explained above, the principles of corporate governance are not a new phenomenon in the Islamic perspective and the objectives of 
the two systems of corporate governance appear to be similar in terms of providing efficient and effective management, adequate disclosure and long-term corporate stability. However, the next point is the main factor that can hinder the implementation of governance in the Islamic perspective, namely:

1. Islamic corporate governance models are related to financial transactions that must comply with Islamic rules, such as prohibiting interest and uncertain transactions. For example, in Islam, records every transaction in a financial report that must reveal the extent to which financing activities and other issues are in accordance with Islamic values.

2. Although Islam has formulated a comprehensive code of ethics and instills accountability, responsibility and justice for people. However, Islamic countries have a poor record of corrupt behavior and fraudulent behavior that will damage any attempt to implement an Islamic corporate governance system.

Shibani \& Fuentes (2017) argued that the Islamic economic seek to social discipline in response to this environment in Islamic countries, it characterized by social commitments ethical norms which are based on moral framework of the Sharia which originated from the Al-Quran and the actions of the prophet Muhammad (Sunnah).Hashim et al(2015) stated that organization that has independent directors, who act as shareholder representative of the organizations will tend, disclose more of its sustainable practices.Therefore, the recommended set of principles of OECD had long been existing since the early stage of Islamic civilization. But, with the globalization tendency and in filtering with the cultural, religious and social, business and political factors, lead to misplace the true ethos of Islamic civilization. Hence, in this present 
situation, the OECD principles have been uccessfully implemented and considered a very effective tool of corporate governance as compared to Islamic principles of corporate governance. In Islamic society the Muslims are permitted to conduct their business activities as guided by the Sharia code of conduct, this code

\subsection{Data Produksi}

encourage the people to be honest, fair and just in their business activities (Tapanjeh, 2009).

According to Tapanjeh (2009), an attempt is made to bring a comparative position of Islamic principles of corporategovernance with the revised principles of OECD.

Table 1

OECD and Islamic Perspective

\begin{tabular}{|c|c|c|}
\hline NO & OECD perspective & Islamic perspective \\
\hline 1 & \multicolumn{2}{|c|}{ Insuring the basis for an effective corporate governance framework } \\
\hline & $\begin{array}{l}\text { Transparent and efficient market } \\
\text { promotion with clear legal rules and } \\
\text { division of corporate organ } \\
\text { responsibility }\end{array}$ & $\begin{array}{ll}\text { - } & \text { Promotion of business within ethical } \\
\text { business framework of Shariah } \\
\text { - } & \text { Believes in profit and loss in business } \\
\text { - } & \text { Justice and social welfare with social } \\
\text { - } & \text { and spiritual obligations } \\
\text { Prohibition of interest }\end{array}$ \\
\hline \multirow[t]{2}{*}{2} & \multicolumn{2}{|c|}{ The rights of shareholders and key ownership functions } \\
\hline & $\begin{array}{ll}\text { - } & \text { Shareholder rights } \\
\text { - } & \text { Participation in Decision-making } \\
\text { - } & \text { Structures and arrangements } \\
\text { - } & \text { } \text { Owarkets for corporate control } \\
\text { - } & \text { Consultative process between } \\
& \text { shareholders and institutional } \\
& \text { shareholders }\end{array}$ & $\begin{array}{ll}\text { - } & \text { Property as trust from God } \\
\text { - } & \text { Sole Authority is God } \\
\text { - } & \text { Society as stakeholders } \\
\text { - } & \text { Accountability not only to } \\
& \text { stakeholders but also to God : the } \\
& \text { ultimate owner }\end{array}$ \\
\hline \multirow[t]{2}{*}{3} & \multicolumn{2}{|l|}{ The equitable treatment of shareholders } \\
\hline & $\begin{array}{l}\text { Protection to minorityshareholders } \\
\text { and foreignshareholders }\end{array}$ & $\begin{array}{l}\text { - } \quad \text { Just and fairness of value } \\
\text { - } \quad \text { Equitable distribution of wealth to all } \\
\text { stakeholders and disadvantages } \\
\text { members in the form of Zakat and } \\
\text { Sadqa } \\
\text { - Social and individual welfare } \\
\text { - Sensation of Equality }\end{array}$ \\
\hline \multirow[t]{2}{*}{4} & \multicolumn{2}{|c|}{ The role of stakeholders in corporate governance } \\
\hline & $\begin{array}{ll}\text { - In creating wealth, jobs and } \\
\text { sustainability of financially sound }\end{array}$ & $\begin{array}{l}\text { - Islamic accountability to Falah and } \\
\text { social welfare orientation }\end{array}$ \\
\hline
\end{tabular}




\begin{tabular}{|c|c|c|}
\hline & enterprises & $\begin{array}{ll}\text { - } & \text { Haram/Halal dichotomy in } \\
\text { transaction } \\
\text { - } & \text { Social \& individual welfare } \\
\text { - } & \text { Consideration to whole community. }\end{array}$ \\
\hline 5 & \multicolumn{2}{|l|}{ Disclosure and transparency } \\
\hline & $\begin{array}{ll}\text { - } & \text { Matters regarding corporation } \\
\text { - } & \text { Financial situation } \\
\text { - } & \text { Performance, ownership and good } \\
& \text { corporate governance }\end{array}$ & $\begin{array}{l}\text { - } \quad \text { Shariah compliance } \\
\text { - Socio-economic objectives related to } \\
\text { firms' control and accountability to } \\
\text { all its stakeholders } \\
\text { - Justice, equality, truthfulness } \\
\text { transparency } \\
\text { - Wider accountability with written as } \\
\text { well } \\
\text { as oral disclosure }\end{array}$ \\
\hline \multirow[t]{2}{*}{6} & \multicolumn{2}{|l|}{ The responsibilities of the board } \\
\hline & $\begin{array}{ll} & \text { Strategic guidance } \\
- & \text { Monitoring of management } \\
\text { - } & \text { Accountability to company and } \\
\text { stakeholders }\end{array}$ & 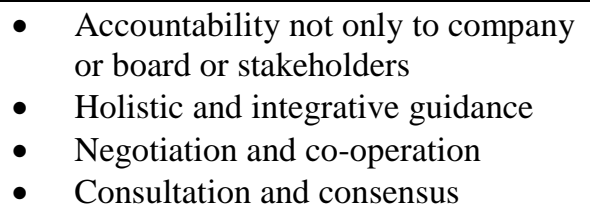 \\
\hline
\end{tabular}

Source : Tapanjeh (2009)

The implementation of the Islamic perspective corporate governance guidelines prioritizes accountability values that have strong implications in every Muslim life that broadly prioritize obligations based on corporate governance guidelines compared to conventional principles. Islamic values are part of the formation of human culture and habits in general, as well as Islamic values in the company that will become guidelines for behaving in regulating or working for the purpose of worship and hoping for the blessing of Allah
SWT. So that in working must apply Islamic values so that it will provide a high morale and will result in the achievement of company goals and performance optimally.

Tapanjeh (2009) states that corporate governance according to the OECD that all shareholders are entitled to the power of decision making and participation of business transactions. The Islamic perspective, anyone associated with stakeholders is given full rights and responsibilities to participate and convey ideas and ideas in reforming better corporate 
governance. And most importantly, Islamic teachings are made to be responsible not only for stakeholders, but also for Allah as the owner and supreme authority. This strong ethics and morality helps in promoting fair, transparent and honest business transactions.

There are similarities in achievement of performance both from an Islamic and conventional perspective. According to Monks \& Minow (2004) that corporate governance is a system that regulates and controls companies to create added value for all stakeholders. There are two things that are focused on the relationship between corporate governance and the achievement of company performance, namely 1) the importance of the right of shareholders to get information correctly and on time; 2) the company has an obligation to make disclosures in an accurate, timely, transparent manner for all information regarding ownership and stakeholders to achieve company performance. The corporate governance framework recognizes the rights of stakeholders as determined by law and encourages collaboration between companies and stakeholders to create stakeholder welfare in achieving business sustainability.

Thus, the results of this study examine the results of the literature reviewed and conclude that corporate governance in Islam is closely related to the achievement of company performance and is expected to provide a general description of the corporate governance framework comprehensively which must recognize the rights of stakeholders as determined by law and encourage the role of active cooperation between companies and stakeholders in creating employee welfare, performance achievement, and corporate sustainability.

\section{Conclusion}

The concept of Islamic corporate governance has a broader scope and there is no separation between roles and responsibilities in all actions and obligations under 
Islamic law. The main difference in the very basic point of view is that corporate governance in an Islamic perspective comes from the values of Tawheed, Sharia, and the concept of Shura. The guidelines for Islamic corporate governance focus on the role of stakeholders, this is the difference between conventional corporate governance (OECD) models and Islamic corporate governance perspectives, which lie in broader stakeholders. This study explains the results of a literature review on the governance of the OECD model and Islamic perspective, although corporate governance in a non-Islamic economy is driven by competition and maximization of shareholder wealth; corporate governance in Islamic economics is based on social welfare criteria to the community. Therefore, the practice of corporate governance in the Islamic perspective must emphasize the use of good governance not only for business enterprises but also for company activities. The limitation of this study is the literature review which is reviewed by perspective which is only seen from the principles of Islamic corporate governance and the principles of conventional governance (OECD and KNKG). Further research will be better if the amount of literature or research reviewed is from various countries and adds more principles, so that a deeper analysis of American, British, European and Japanese Business Network models with different conditions can be done, so that they will be obtained understanding the concept of better corporate governance guidelines.

\section{REFERENCES}

Anand, S. (2008). Essentials of Corporate

Governance. Canada : John Wiley \& Sons, Inc

Agustian, A.G. (2009). Spiritual Company:Kecerdasan Spititual Pembawa Sukses Kampiun Bisnis Dunia. Jakarta:Arga Publishing

Brennan, N. M., \& Solomon, J. (2008). Corporate Governance, Accountability and Mechanisms of Accountability 
: An Overview. Accounting, Auditing\& Accountability Journal, 21 (7)

Chapra, M., \& Ahmed, H. (2002). Corporate Governance in Islamic Financial Institutions. Jeddah : Islamic

Effendi, M. A. (2016). The Power of Good Corporate Governance.Edisi 2. Jakarta : Salemba Empat

Hasan, Z. (2009). Corporate Governance : Western and. International Review of Business Research Papers, 2 (9)

Hashim, F., Mahadi, N. D., \& Amran, A. (2015). Corporate Governance and Sustainability Practices in Islamic. Procedia Economics and Finance, 31 (43)

Hayat, R., \& Hassan, M. K. (2016). Does an Islamic Label Indicate Good Corporate Governance? Journal of Corporate Finance, 10(8)

Indrawaty, \& Wardayati, S. M. (2016). Implementing Islamic Corporate Governance (ICG) and Islamic Social Reporting (ISR) in Islamic Financial Institution (IFI). Journal of Social and Behavioral Science, 21 (39)

Iqbal, Z., \& Mirakhor, A. (2012). Financial Inclusion : Islamic
Finance Perspective. Journal of Islamic Business and Management, 2 (1)

Jensen, M. C. (2000). Us Corporate Governance: Lessons from the 1980's. Wiley : John Leslie Livingstone

Kakabadse Nada K., Linda Lee D., Cicile R.(2005). Corporate Social Responsibility and Stakeholder Approach : A Conceptual

Review.International Journal of Business Governance and Ethics, 1(4)

Lukviarman, N. (2016). Corporate Governance : Menuju Penguatan Konseptual Dan Implementasi Di Indonesia. Jakarta: Era Adicitra Intermedia

Mansor, M. L. (2015). Islamic Perspective of Corporate Governance. University Bulletin, 17(1)

Monks, R., \& Minow, N. (2004). Corporate Governance. Boston : Blackwell Publisher

OECD. (1999). OECD Principles of Corporate Governance. Danvers: Meeting of the OECD Council

Ramli, J. A., \& Ramli, M. I. (2016). Corporate Governance and Corporate Performance of Malaysian Companies: Examining from an Islamic 
Perspektive. Journal of Economics and Finance, 35 (16)

Shaw, J. C. (2003). Corporate Governance and Risk: A System Approach. New Jersey: John Wiley \& Sons, Inc

Shibani, O., \& Fuentes, C. D. (2017). The differences and the similarities between corporate. Journal of Research in International Business and Finance, 11 (29)

Steiner, J. F., \& Steiner, G. A. (2009). Business, Government, and Society: A Managerial
Perspective, Text and Cases. Boston: McGraw-Hill

Tapanjeh, A. M. (2009). Corporate governance from the Islamic perspective:. Critical Perspectives on Accounting, 20 (5)

Tikawati. (2016). Pengaruh Corporate Governance, Growth Opportunity dan Net Profit. Jurnal Ekonomi dan Bisnis Islam, 1 (2)

Tricker, R. I. (2009). Corporate Governance: Principles, Policies, and Practices. UK: Oxford University Press 
Appendix 1. Results Of Previous Studies

\begin{tabular}{|c|c|c|c|c|c|}
\hline \multirow[t]{2}{*}{ No } & \multirow{2}{*}{$\begin{array}{c}\text { Authors } \\
\text { Title } \\
\text { Publication }\end{array}$} & \multirow{2}{*}{$\begin{array}{l}\text { Objectives of the Study and the } \\
\text { Related Variables }\end{array}$} & \multicolumn{3}{|c|}{ Methodology } \\
\hline & & & $\begin{array}{l}\text { Res. } \\
\text { design }\end{array}$ & Sample & Instrument \\
\hline 1 & $\begin{array}{l}\text { Fathyah } \\
\text { Hashima, } \\
\text { Nur Darina } \\
\text { Mahadia, } \\
\text { Azlan } \\
\text { Amrana } \\
\text { (2015) } \\
\text { Corporate } \\
\text { Governance } \\
\text { and } \\
\text { Sustainabili } \\
\text { ty Practices } \\
\text { in Islamic } \\
\text { Financial } \\
\text { Institutions: } \\
\text { The Role of } \\
\text { Country of } \\
\text { Origin. } \\
\text { Procedia } \\
\text { Economics } \\
\text { and } \\
\text { Finance } \\
\text { 31(36 - 43) }\end{array}$ & $\begin{array}{l}\text { Objectives: } \\
\text { This study examines the role of country } \\
\text { of origin on the relationship between } \\
\text { corporate governance and sustainability } \\
\text { practices in Islamic Financial } \\
\text { Institutions (IFIs). Variables: } \\
\text { Sustainability practices; Islamic } \\
\text { Financial Institutions; Shariah } \\
\text { Supervisory Board; corporate } \\
\text { governance; country of origin }\end{array}$ & $\begin{array}{l}\text { Quanti } \\
\text { tative } \\
\text { metho } \\
\mathrm{d} \text {, } \\
\text { using a } \\
\text { regress } \\
\text { ion } \\
\text { linear } \\
\text { and } \\
\text { descri } \\
\text { ptive } \\
\text { statisti } \\
\text { cs }\end{array}$ & $\begin{array}{l}\text { The } \\
\text { populat } \\
\text { ion for } \\
\text { this is } \\
\text { all } \\
\text { Islamic } \\
\text { Financi } \\
\text { al } \\
\text { Institut } \\
\text { ions in } \\
\text { the } \\
\text { world } \\
\text { that } \\
\text { issue } \\
\text { annual } \\
\text { report } \\
\text { for } \\
\text { year } \\
2011 \\
\text { and } \\
2012 . \\
\text { The } \\
\text { sampli } \\
\text { ng } \\
\text { techniq } \\
\text { ue } \\
\text { used } \\
\text { for this } \\
\text { study } \\
\text { is } \\
\text { conven } \\
\text { ient } \\
\text { sampli } \\
\text { ng. }\end{array}$ & $\begin{array}{l}\text { Adapted } \\
\text { from } \\
\text { based on } \\
\text { research by } \\
\text { Choudhury } \\
\text { \& Hoque, } \\
2006, \\
\text { Chakrabarty } \\
\text { and Liang, } \\
2012\end{array}$ \\
\hline 2 & $\begin{array}{l}\text { Raphie } \\
\text { Hayat, M. } \\
\text { Kabir } \\
\text { Hassan } \\
\text { (2016) } \\
\text { Does an }\end{array}$ & $\begin{array}{l}\text { Objectives: } \\
\text { In this paper we study the effect of an } \\
\text { Islamic label on corporate governance. } \\
\text { Listed firms with an Islamic label } \\
\text { (Islamic firms) are characterized by } \\
\text { low leverage. } \\
\text { Variables: }\end{array}$ & $\begin{array}{l}\text { Quantitat } \\
\text { ive } \\
\text { method, } \\
\text { using a } \\
\text { regressio } \\
\text { n linear } \\
\text { and }\end{array}$ & $\begin{array}{l}\text { S\&P } \\
500 \\
\text { firms } \\
\text { from } \\
2010 \text { to } \\
2012\end{array}$ & $\begin{array}{l}\text { Adapted } \\
\text { from } \\
\text { based on } \\
\text { Islamic } \\
\text { finance } \\
\text { industryT } \\
\text { homson }\end{array}$ \\
\hline
\end{tabular}




\begin{tabular}{|c|c|c|c|c|}
\hline & $\begin{array}{l}\text { Islamic } \\
\text { Label } \\
\text { Indicate } \\
\text { Good } \\
\text { Corporate } \\
\text { Governance } \\
\text { Journal of } \\
\text { Corporate } \\
\text { Finance }\end{array}$ & $\begin{array}{l}\text { Islamic finance, corporate governance, } \\
\text { leverage, agency problems }\end{array}$ & $\begin{array}{l}\text { descripti } \\
\text { ve } \\
\text { statistics }\end{array}$ & $\begin{array}{l}\text { Reuters, } \\
2015, \\
\text { Beck et } \\
\text { al., } 2013\end{array}$ \\
\hline 3 & $\begin{array}{l}\text { Abdussalam } \\
\text { Mahmoud } \\
\text { Abu- } \\
\text { Tapanjeh } \\
(2009) \\
\text { Corporate } \\
\text { governance } \\
\text { from the } \\
\text { Islamic } \\
\text { perspective: } \\
\text { A } \\
\text { comparative } \\
\text { analysis } \\
\text { with OECD } \\
\text { principles } \\
\text { Critical } \\
\text { Perspective } \\
\text { s on } \\
\text { Accounting } \\
20 \text { (2009) } \\
556-567\end{array}$ & $\begin{array}{l}\text { Objectives: } \\
\text { This paper is an attempt to discuss the } \\
\text { nature,applications and comparison of } \\
\text { Islamic principles of corporate } \\
\text { governance (IPCG) with conventional } \\
\text { principles of corporate governance } \\
\text { considering special reference to } \\
\text { Organization of Economic Co- } \\
\text { operation and Development (OECD). } \\
\text { behaviour } \\
\text { Variables: } \\
\text { corporate governance }\end{array}$ & $\begin{array}{l}\text { Qualitati } \\
\text { ve }\end{array}$ & $\begin{array}{l}\text { Adapted } \\
\text { from } \\
\text { based on } \\
\text { research } \\
\text { byDen } \\
\text { Berghe, } \\
2001 \text {, } \\
\text { Dalton et } \\
\text { al } 2003\end{array}$ \\
\hline 4 & $\begin{array}{l}\text { Osama } \\
\text { Shibani, } \\
\text { Cristina De } \\
\text { Fuentes } \\
\text { (2017) } \\
\text { The } \\
\text { differences } \\
\text { and the } \\
\text { similarities } \\
\text { between } \\
\text { corporate } \\
\text { governance } \\
\text { principles } \\
\text { in Islamic }\end{array}$ & $\begin{array}{l}\text { Objectives: } \\
\text { The purpose of this paper is to present } \\
\text { the differences and similarities between } \\
\text { corporate governance principles in } \\
\text { Islamic banks and conventional banks } \\
\text { by paradigmatic diversification. } \\
\text { Variables: } \\
\text { Corporate governance, Islamic banks, } \\
\text { Conventional banks, Paradigms }\end{array}$ & $\begin{array}{l}\text { Qualitati } \\
\text { ve }\end{array}$ & $\begin{array}{l}\text { Adapted } \\
\text { from } \\
\text { stakehold } \\
\text { ers and } \\
\text { managers } \\
\text { Iqbal and } \\
\text { Mirakhor, } \\
2004 \text { and } \\
\text { Hasan, } \\
2009 \text {. }\end{array}$ \\
\hline
\end{tabular}




\begin{tabular}{|c|c|c|c|c|c|}
\hline & $\begin{array}{l}\text { banks and } \\
\text { Convention } \\
\text { al banks } \\
\text { Research in } \\
\text { Internationa } \\
\text { 1 Business } \\
\text { and Finance }\end{array}$ & & & & \\
\hline 5 & $\begin{array}{l}\text { Tikawati } \\
\text { (2016) } \\
\text { Implementa } \\
\text { si Good } \\
\text { Corporate } \\
\text { Governance } \\
\text { Pada } \\
\text { Lembaga } \\
\text { Keuangan } \\
\text { Syariah } \\
\text { (Perbankan } \\
\text { Syariah) } \\
\text { Jurnal } \\
\text { Ekonomi } \\
\text { dan Bisnis } \\
\text { Islam, 1 (2) }\end{array}$ & $\begin{array}{l}\text { Objectives: } \\
\text { Implementation of good corporate } \\
\text { governance in Islamic financial } \\
\text { institutions } \\
\text { Variables: } \\
\text { Good corporate governance }\end{array}$ & $\begin{array}{l}\text { Qualitati } \\
\text { ve }\end{array}$ & - & $\begin{array}{l}\text { Adapted } \\
\text { from } \\
\text { stakehold } \\
\text { ers and } \\
\text { managers } \\
\text { McGee, } \\
\text { Robert W. } \\
2008, \\
\text { Chapra } \\
\text { dan } \\
\text { Habib, } \\
2002\end{array}$ \\
\hline 6 & $\begin{array}{l}\text { Abbas } \\
\text { Mirakhor } \\
\text { and Zamir } \\
\text { Iqbal } \\
(2012) \\
\\
\text { Financial } \\
\text { Inclusion: } \\
\text { Islamic } \\
\text { Finance } \\
\text { Perspective } \\
\text { Journal of } \\
\text { Islamic } \\
\text { Business } \\
\text { and } \\
\text { Managemen } \\
\text { t } 2 \text { (1) }\end{array}$ & $\begin{array}{l}\text { Objectives: } \\
\text { This paper argues that conventional } \\
\text { model of enhancing financial inclusion } \\
\text { can be replicated through instruments } \\
\text { of Islamic finance allowing risk sharing } \\
\text { and risk diversification } \\
\text { Variables: } \\
\text { financial inclusion, risk sharing and } \\
\text { risk diversification }\end{array}$ & $\begin{array}{l}\text { Qualitati } \\
\text { ve }\end{array}$ & - & $\begin{array}{l}\text { Adapted } \\
\text { from } \\
\text { Redistribu } \\
\text { tive } \\
\text { Instrumen } \\
\text { ts of } \\
\text { Islam } \\
\text { Mirakhor } \\
\text { and } \\
\text { Askari, } \\
2010\end{array}$ \\
\hline
\end{tabular}

\section{Appendix 1. Results Of Previous Studies (continued)}




\begin{tabular}{|c|c|c|c|}
\hline No & $\begin{array}{c}\text { Analysis } \\
\text { Techniques }\end{array}$ & Result & Comments / Gaps \\
\hline 1 & $\begin{array}{l}\text { regression } \\
\text { linear }\end{array}$ & $\begin{array}{l}\text { The study found that the board size, directors' } \\
\text { independence, and the aspects of } \\
\text { environmental, social and profit in the mission } \\
\text { and/or vision have positive relationship for IFIs } \\
\text { in GCC countries. However, the size of SSB is } \\
\text { found to have insignificant relationship with the } \\
\text { sustainability practices of IFIs. The country of } \\
\text { origin is found to have a moderating role on the } \\
\text { relationships between all of the corporate } \\
\text { governance dimensions with sustainability } \\
\text { practices except for the size of SSB and } \\
\text { sustainability practices relationship. }\end{array}$ & $\begin{array}{l}\text { This implies that the } \\
\text { size of SSB of IFIs in } \\
\text { GCC countries does not } \\
\text { have a great influence } \\
\text { towards sustainability } \\
\text { practices as compared to } \\
\text { the size of SSB in non- } \\
\text { GCC countries }\end{array}$ \\
\hline 2 & $\begin{array}{l}\text { regression } \\
\text { linear } \\
\text { equation } \\
\text { modeling }\end{array}$ & $\begin{array}{l}\text { The results showed that no significant } \\
\text { differences in corporate governance quality } \\
\text { between Islamic } \\
\text { and non-Islamic S\&P } 500 \text { firms. }\end{array}$ & $\begin{array}{l}\text { Future research on the } \\
\text { suggests that the Islamic } \\
\text { label should explicitly } \\
\text { include ESG criteria in } \\
\text { their screening process. } \\
\text { Incorporating these } \\
\text { criteria would much } \\
\text { better uphold the } \\
\text { principles of } \\
\text { Islam. }\end{array}$ \\
\hline 3 & $\begin{array}{l}\text { Literature } \\
\text { review }\end{array}$ & $\begin{array}{l}\text { It discusses above the current state of corporate } \\
\text { governance practices at the conventional } \\
\text { economy and established the measurement of } \\
\text { good corporate governance at the functional } \\
\text { level, compared from Islamic perspectives }\end{array}$ & $\begin{array}{l}\text { OECD principles have } \\
\text { been successfully } \\
\text { implemented and } \\
\text { considered a very } \\
\text { effective tool of } \\
\text { corporate governance as } \\
\text { compared to Islamic } \\
\text { principles of corporate } \\
\text { governance. }\end{array}$ \\
\hline 4 & $\begin{array}{l}\text { Literature } \\
\text { review }\end{array}$ & $\begin{array}{l}\text { Corporate governance from the radical } \\
\text { humanist paradigm considers that corporate } \\
\text { governance models are chosen through a fair } \\
\text { and democratic process. In this paradigm view } \\
\text { of the Islamic corporate governance depends on } \\
\text { the principle of consultation (Shura principle) } \\
\text { between all stakeholders in the bank }\end{array}$ & $\begin{array}{l}\text { the reason for the } \\
\text { existence of governance } \\
\text { in Islamic banks is a } \\
\text { turning point for the } \\
\text { unwillingness of people } \\
\text { in Islamic society to } \\
\text { deal with banking } \\
\text { interests which are } \\
\text { forbidden in the Islamic } \\
\text { religion }\end{array}$ \\
\hline
\end{tabular}




\begin{tabular}{|c|c|c|c|}
\hline 5 & $\begin{array}{l}\text { Literature } \\
\text { review }\end{array}$ & $\begin{array}{l}\text { Implementation of good corporate governance } \\
\text { in Islamic financial institutions become } \\
\text { increasingly important to do that foster trust } \\
\text { within the community and improve the } \\
\text { performance and progress of Islamic banking. } \\
\text { GCG in the body of Islamic institutions is } \\
\text { crucial to the development of Islamic banking } \\
\text { towards the more advanced. In principle, the } \\
\text { GCG implementation of relevant and in line } \\
\text { with Islamic values. Islam requires that every } \\
\text { aspect of life regulated by systems and } \\
\text { structures that meet the best practices outlined } \\
\text { by Allah SWT }\end{array}$ & $\begin{array}{l}\text { Two ideals must go } \\
\text { hand in hand. GCG } \\
\text { become an integral part } \\
\text { of the Islamic concept of } \\
\text { a full and thorough. }\end{array}$ \\
\hline 6 & $\begin{array}{l}\text { Literature } \\
\text { review }\end{array}$ & $\begin{array}{l}\text { The redistributive instruments may be } \\
\text { developed as proper institutions to optimize the } \\
\text { functions of such instruments }\end{array}$ & $\begin{array}{l}\text { Application of financial } \\
\text { engineering can device } \\
\text { innovative ways to } \\
\text { develop hybrids of risk } \\
\text { sharing and risk } \\
\text { diversification }\end{array}$ \\
\hline
\end{tabular}

